Jurnal Pakarena

Volume 5 Nomor 2, Desember 2020

e-ISSN: 2550-102X dan p-ISSN: 1693-3990

This work is licensed under a Creative Commons Attribution

4.0 International License

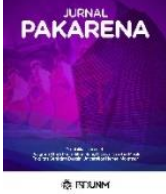

\title{
ANALISIS KARAKTER PANGERAN BADAR DALAM PERTUNJUKAN TEATER BANGSAWAN PALEMBANG (NASKAH DUA KORBAN DI GUNUNG MERU)
}

\section{Zul Id'Han}

Keywords :

Teater Bangsawan;

Karakter; Penokohan

Corespondensi Author

Prodi Pendidikan Seni

Pertunjukan STKIP

Muhammadiyah Oku

Timur

Email:

zulidhan6@gmail.com

History Artikel

Received: 02-11-2020

Reviewed: 02-11-2020

Revised: 28-12-2020

Accepted: 29-12-2020

Published: 30-12-2020

\begin{abstract}
ABSTRAK
Penelitian berjudul "Analisis karakter Pangeran Badar dalam pertunjukan Teater Bangsawan Palembang" ini berusaha untuk menterjemahkan Karakter tokoh pada lakon teater Bangsawan dengan pendekatan teori psikologi dan teori penokohan. Untuk menjawab permasalahan tersebut maka peneliti membuat beberapa pertanyaan dalam rumusan masalah yang berkaitan dengan: 1. Bagaimana sikap, perilaku, dan nada bicara Pangeran Badar kepada tokoh yang lain, 2. Seperti apakah pola pikir Pangeran Badar terhadap tokoh yang lain. dan 3. Seperti apakah peran Pangeran badar pada sudut pandang Penokohan. Adapun metode yang di gunakan dalam pengumpulan data adalah diskriftif analisis. Metode pengumpulan data dilakukan dengan observasi, studi pustaka, wawancara, dan dokumentasi. Lakon Dua Korban di Gunung Meru merupakan karya Johar Saad, dan karakter tokoh dari Pangeran Badar menjadi sosok terpenting dalam lakon tersebut, karena pada sebuah penampilan teater akan muncul sebuah konflik yang di bangun oleh tokoh-tokoh. Hasil penelitian ini memberikan sebuah analisis pengambaran kehidupan cerita yang dibangun pada konsep teater bangsawan yang dapat dipetik pembelajaran di dalamnya, Bagian terpenting adalah mengacu terhadap tokoh yang menjadi sasaran jalan cerita, tabiat atau karakter yang muncul dari Pangeran Badar merupakan cerminan karakter antagonis seorang penguasa yang arogan hingga akhir hayatnya.
\end{abstract}

\section{PENDAHULUAN}

Psikologi umum menyebutkan bahwa karakter adalah istilah bahasa Belanda yakni characterologie, character berarti watak dan logie berarti ilmu, jadi characterologie adalah ilmu yang mengkaji watak dan perilaku manusia atau cara tindakan seseorang lewat perilakunya. Dengan demikian, perilaku atau cara tindakan seseorang akan meninggalkan bekas goresan-goresan sekaligus menjadi stempel yang bermakna mencerminkan jiwa pribadinya (Tasman, 2008:13).
Karakter adalah tabiat atau kebiasaan, menurut ahli psikologi, karakter adalah sebuah sistem keyakinan dan kebiasaan yang mengarahkan tindakan seorang individu. Oleh karena itu, jika pengetahuan mengenai karakter seseorang itu dapat diketahui, maka dapat diketahui pula bagaimana individu tersebut akan bersikap untuk kondisi-kondisi tertentu (Singh dan Agwan, 2000:175).

Karakter menjelaskan perbedaan yang prinsip diantara satu dengan yang lainya. Dalam hal ini karakter dibedakan menjadi 3, 
Zul Id han, Analisis Karakter Pangeran Badar Dalam Pertunjukan Teater Bangsawan Palembang (Naskah Dua Korban Di Gunung Meru).

yaitu karakter berdasarkan kontruksi jasmaniah (tipologi), temperament, dan watak. Tipologi merupakan karakter yang mempunyai ciri berdasarkan konstitusi jasmaniah, ialah keadaan individu secara fisionologis sebab adanya sifat-sifat yang dibawa sejak lahir.

Temperament, adalah sifat-sifat dan kejiwaan seseorang disebabkan oleh adanya campuran zat di dalam tubuhnya, sehingga mempengaruhi tingkah laku. Temperament erat hubungannya terhadap faktor-faktor biologis atau fisiologis yang sedikit sekali mengalami modifikasi di dalam perkembangannya. temperament adalah bagian khusus dari keperibadian yang diberi definisi, temperament adalah gejala karakteristik dari pada sifat individu kena rangsangan emosi, kekuatan serta kecepatanya bereaksi, kwalitas kekuatan hatinya, segala cara dari pada fluktuasi dan intensitas suasana hati, gejala ini tergantung pada faktor kontitusional terutama berasal dari keturunan (Tasman, 2008:20).

Karakter juga erat kaitannya dengan etika dan moral dari pribadi.Etika berasal dari bahasa Yunani Kuno. Kata Yunani ethos yang memiliki definisi dalam pengetahuan tentang asas-asas akhlak. Sebenarnya, kata etika mengarah kepada baik atau tidak baik pribadi manusia yang dapat terlihat dari pembawaannya, menyangkut cara manusia beradaptasi dengan sesamannya ketika berinteraksi. Perilaku manusia sebenarnya memiliki sifat yang di bawanya dalam kehidupan sehari-hari etika adalah, pemaknaan atas diri terhadap orang lain, dan orang lain terhadap dirinya (Bertens, 1993:4).

Karakter dalam arti watak ialah peribadi jiwa yang menyatakan dirinya dalam segala tindakan dan pernyataan. Karakter ditinjau dari limu watak adalah tingkah laku atau perilaku tindakan sebagai pernyataan peribadi jiwanya. Hubungan antara perilaku atau tindakan dengan gambaran jiwa dapat dilihat sebagai hubungan bentuk pisik dan makna jiwa. Perilaku atau tindakan adalah cara berlaku atau bertindak untuk suatu maksud tujuan yang sangat pribadi, suatu tindakan adalah cara penggunaan bahan dan bentuk. Untuk mengungkapkan rasa gembira seseorang dapat menggunakan simbol bentuk kata-kata ataupun kalimat, tertawa, atau gerakan tertentu, bahkan dalam bentuk isyarat yang lainya.

Berbicara tentang karakter erat kaitannya dengan pikiran karena pikiran mempengaruhi karakter, bahkan menjadi suatu bentuk interaksi dengan lawan interaksi.Tentang pikiran, Joseph Murphy mengatakan bahwa di dalam diri manusia terdapat satu pikiran yang memiliki ciri yang berbeda. Untuk membedakan ciri tersebut, maka istilahnya dinamakan dengan pikiran sadar (conscious mind) atau pikiran objektif dan pikiran bawah sadar (subconscious mind) atau pikiran subjektif (Murphy, 2002:6). Karakter seorang aktor juga dapat diartikan melalui nada bicara dari seorang aktor tersebut, karena dialog yang disampaikan memiliki struktur dimensi penekanan katakata melalui cara bicara yang dikeluarkan. Kita akan dapat mengetahui tekanan emosional dari seorang aktor ketika merasakan penyampaian kata kepada aktor lain dalam adegan. Dalam teori drama menurut Waluyo ada empat (4) elemen artikulasi.

“...(1) Volume (Kekuatan vokal), Kekuatan vokal adalah seberapa besar kekuatan seorang aktor dalam menguasai ruangan (penonton), sehingga suara tidak hanya terdengar oleh penonton yang duduk di bagian depan tapi juga sampai ke bagian paling belakang. Volume sangat dipengaruhi oleh pernafasan perut (diafragma)...kemudian, (2) Tekanan (intonasi). Tekanan diterapkan pada satu bagian kata untuk menetapkan pentingnya sebuah kata atau permaknaannya. Tempo dan Pause (durasi). (3) Tempo adalah durasi pengucapkan sebuah kata atau kalimat, yang terakhir adalah nada, (4) nada 
adalah tinggi rendahnya suara. Nada tinggi biasanya dipakai untuk ekspresi tegang dan kemarahan, sedang nada rendah untuk ekspresi ketenangan atau dingin. Dengan kata lain, nada bisa sangat berguna untuk membuat karakter. Selain itu nada juga bisa dipakai untuk memuat dialek...' (Waluyo, 2007:178-179).

Berbicara merupakan suatu kemampuan mengucapkan bunyi-bunyi artikulasi atau kata-kata untuk mengekspresikan, menyatakan atau menyampaikan pikiran, gagasan dan perasaan. Berbicara adalah suatu alat untuk mengkomunikasikan gagasangagasan yang disusun sertadikembangkan sesuai dengan kebutuhan-kebutuhan pendengar atau penyimak. Kemampuan berbicara adalah kemampuan mengucapkan bunyi-bunyi artikulasi atau mengucapkan kata-kata untukmengekspresikan, menyatakan, menyampaikan pikiran, gagasan dan perasaan. Dengan memahami nada bicara aktor dapat dilihat seperti apa karakter aktor dalam sebuah adegan, termasuk interaksinya dengan aktor yang lain (Waluyo, 2007:180).

Lakon Dua Korban di Gunung Meru mengkisahkan tentang karakter seorang pangeran yang bernama Pangeran Badar, pangeran yang memiliki harta dan kekuasaan dari kerajaan yang melimpah menjadikan pangeran memiliki sifat dan sikap yang angkuh serta kejam. Pangeran Badar senang berpoya-poya dan minum-minuman. Ini merupakan sifat buruk yang acap kali dilakukan Pangeran Badar baik di dalam dan luar Istana.

Karakter yang dimiliki oleh Pangeran Badar merupakan karakter dari tokoh penguasa, menyinggung persoalan penguasa menurut Abraham Maslow pendiri psikologi humanis, sosok penguasa erat juga kaitannya dengan kemampuan menguasai segala sesuatu dan elemen apapun seperti status (Maslow, 1994:115). Status pangeran berbeda dengan keadaan masyarakat biasa, faktor inilah yang mengakibatkan seorang pangeran dalam cerita ini memiliki watak yang arogan, angkuh, dan sombong.

Mencermati tentang kekuasaan menurut pernyataan Robert bahwa kekuasaan merujuk pada adanya kemampuan mempengaruhi dari satu pihak kepada pihak lain, jadi Kekuasaan merupakan kemampuan seseorang dalam mempengaruhi pikiran atau tingkah laku orang lain. Kemampuan tersebut akan menjadi cerminan yang dilihat oleh orang terhadapnya, ketika orang sudah terpengaruh atas citranya maka di saat itu pula rasa simpatik dan pengakuan atas diri muncul (Robert A. Dahl 1978:29).

Kekuasaan Pangeran Badar tidak bisa ditentang oleh siapapun, terutama masalah pasangan hidup. Pangeran berhak memilih siapa saja yang diinginkannya, dan mempermainkan perasaan wanita dengan bujuk rayu dan kekuasaan yang dimilikinya. Ini merupakan cerminan dari perilaku seorang pangeran dalam lakon Dua Korban di Gunung Meru.

Kekuasaan tentu tidak begitu saja diperoleh, ada proses dan hal yang menunjang untuk menempatkan diri pada pemegang kekuasaan.Sumber kekuasaan itu sendiri sangatlah bermacam-macam ada dengan kekayaan, sarana paksaan fisik, keahlian, serta kedudukan.

'Kekuasaan pada dasarnya dianggap sebagai suatu hubungan, karena pemegang kekuasaan menjalankan kontrol atas sejumlah orang lain. Pemegang kekuasaan bisa jadi seseorang individu atau sekelompok orang, demikian juga obyek kekuasaan bisa satu atau lebih dari satu' (Charles F. Andrain, 1992:130).

Kekayaan merupakan sumber kekuasaan yang dapat berupa uang, emas, tanah dan barang-barang berharga.Orang yang memiliki kekayaan dalam jumlah besar setidak-tidaknya secara potensial akan memiliki kekuasaan. Misalnya seorang tuan tanah mempunyai lahan perkebunan yang 
luas dan tuan tanah tersebut secara langsung mempunyai kekuasaan atas pekerja-pekerja di tanah tersebut, kemudian sarana paksaan fisik merupakan sumber kekuasaan yang lebih bersifat memaksa, sehingga membuat orang lain dapat mengikuti apa yang dikehendaki. Misal seorang penguasa untuk mempengaruhi pola perilaku orang lain, penguasa tersebut menggunakan senjata sebagai ancaman, dan dalam hal ini secara tidak langsung dapat kita lihat bahwa penguasa tersebut dapat mempengaruhi pola perilaku orang lain dengan ancaman senjata yang dimiliki.

Kekuasaan dapat diperoleh dari kedudukan. Kedudukan dapat memberikan kekuasaan kepada seseorang atau sekelompok orang karena yang bersangkutan menduduki posisi sebagai pemegang kekuasaan. Kedudukan merupakan sumber kekuasaan yang timbul karena adanya pengakuan sehingga secara sah dapat mempengaruhi perilaku (Haryanto, 2005:22).

Pola pikir Pangeran Badar terhadap tokoh lain dalam lakon menimbulkan asumsi, bahwa status pangeran memiliki segalanya dan prilaku ini mengarah kepada tindakan semena-mena, karena apapun yang diinginkan pangeran tidak bisa ditentang oleh siapapun. Tapi pangeran justru menyalahgunakan status kekuasaan yang dimiliki. Status sosial biasanya diekpresikan dengan fakta bahwa bagaimanapun juga, gaya hidup mempengaruhi interaksi. Gaya hidup menempatkan, dan mementukan status manusia di dalam kehidupannya (Weber, 2006:225).

Tinjauan pustaka diharapkan dapat memberikan acuan bagi penulis dalam penelitian ini, sumber-sumber tulisan digunakan sebagai arahan penulis untuk melihat originalitas dari penelitian berupa, tesis, jurnal serta karya ilmiah lainya.

Pada buku A. Tasman yang berjudul "Analisa Gerak dan Karakter" yang diterbitkan oleh ISI Pres Surakarta (2008), dalam tulisannya A. Tasman membahas tentang analisis gerak, konsep gerak, dan karakter dalam seni tari. Tulisan ini mengarah kepada konsep gerak dan karakter di dalam sebuah tarian, tulisan ini juga membahas karakter walaupun objeknya berbeda analisis yang digunakan dapat dijadikan acuan bagi peneliti untuk memahami karakter. Penelitian yang akan penulis lakukan, yaitu tentang "karakter Pangeran Badar dalam Lakon dua Korban di Gunung Meru " berbeda dengan tulisan ini, meskipun demikian buku yang telah ditulis oleh A. Tasman sangat bermanfaat bagi peneliti sebagai salah satu sumber inspirasi.

Selanjutnya dalam tesis yang ditulis oleh Mei Ambar Sari berjudul "Analisis Karakter dan Konflik Tokoh Utama dalam Novel Bochan karya Nathusme Sousakhi" (2011), membahas mengenai konflik aktor satu dengan aktor lainya dalam tulisan tersebut konflik antar tokoh diselesaikan menggunakan kekerasan. Perbedaan penelitian yang akan penulis lakukan dengan tulisan Mei Ambar Sari adalah bahwa, tulisan ini digunakan untuk menganalisis karakter tokoh dalam novel, analisis yang digunakan dalam menelaah karakter tokoh dalam novel, adalah teori pengkajian fiksi. Dari sumber bacaan ini dapat penulis jadikan inspirasi dalam menelaah karakter Pangeran Badar karena, karakter dalam penelitian dipandang dari sisi sastra jadi tulisan ini sangat penting bagi penulis sebagai referensi namun penelitian yang akan dilakukan tidaklah sama baik objek dan isinya, cara analisis mungkin saja bisa di pakai karena berkaitan dengan pengambaran karakter, namun asfek dalam melukiskan karakter dalam novel dan karakter pada tokoh lakuan jelas tidak sama. Meskipun demikian tulisan ini bermanfaat bagi peneliti sebagai inspirasi dan acuan yang mengkaji masalah karakter.

Jurnal Dwina Novi Jayanti yang berjudul"Kepribadian Tokoh Uemura Kana Dalam Drama Toire No Kamisama"Program Studi Sastra Jepang, Universitas Dian Nuswantoro(2012), meneliti tentang kepribadian tokoh Uemura Kana dalam drama Toire no Kamisama dari sisi 
psikologis. Tujuan penelitian ini adalah untuk mengetahui kepribadian tokoh Uemura Kana dilihat dari Id, Ego dan Super Ego dalam diri tokoh tersebut, serta konflik yang dialami oleh tokoh tersebut. Perbedaan penelitian yang akan penulis lakukan dengan tulisan Dwina Novi Jayanti adalah dari segi penjelasan karakter tidak dilihat dari sisi kepribadian saja tetapi juga dilihat dari nada bicara seorang aktor dan cara berinteraksi seorang aktor terhadap tokoh yang lain, meskipun demikian tulisan ini tetap bermanfaat bagi peneliti sebagai sumber inspirasi yang mengkaji masalah karakter.

\section{Metode Penelitian}

Berdasarkan masalah yang dikaji penelitian ini merupakan sebuah bentuk penelitian kualitatif dengan metode deskriftif analisis terhadap karakter tokoh Pageran Badar dalam lakon dua korban di Gunung Meru. Berdasarkan manfaat empiris, bahwa metode pengumpulan data kualitatif yang paling independen terhadap semua metode pengumpulan data dan teknik analisis data adalah metode wawancara mendalam, observasi partisipasi, dan bahan dokumenter (Burgin, 2010:107).

Dalam penelitian ini peneliti sebagai intrumen utama dalam mengumpulkan data. Sumber data yang akan menjadi sasaran penelitian adalah visual penampilan Teater Bangsawan di Kota Palembang. Penampilan teater SHJ baik yang dilihat dari dokumentasi produksi stasiun TVRI Sumatera Selatan, dan dokumentasi sendiri yang didapatkan pada saat melihat secara langsung pertunjukan Teater Bangsawan yang di bawakan oleh Teater Bangsawan SHJ diberbagai kesempatan penampilan.

Kota Palembang merupakan pusat kota yang ada di Sumatera Selatan. Seni pertunjukan Teater Bangsawan berkembang di seluruh Sumatera Selatan, salah satu garapan dari SHJ dengan lakon Dua Korban Di Gunung Meru adalah dokumentasi rekaman yang akan diteliti. Pangeran Badar merupakan fokus utama di dalam penelitian ini. Penulis akan melihat dan meneliti secara langsung dari menampilan Teater Bangsawan yang ditampilkan maupun analisis naskah.

\section{Hasil Penelitian dan Pembahasan}

Pangeran Badar dalam lakon Dua Korban di Gunung Meru memiliki temperament yang jahat, karena pada setiap kemunculannya menunjukkan hal yang buruk, seperti berbicara kasar, melakukan tindakan yang tidak seharusnya dilakukan oleh seorang pangeran kepada rakyat dan orang disekitarnya. Pangeran Badar bertindak kasar terhadap kekasihnya dalam cerita Dua Korban Di Gunung Meru dan berdalih tidak mengakui hubungannya, agar tidak diketahui oleh siapapun bahkan masyarakat istana kala itu, karena merasa malu memiliki hubungan spesial dengan rakyat biasa.

Secara psikologis prilaku Pangeran Badar adalah bentuk sikap bawaan dan menjadi jati dirinya. Sifat dan sikap ditentukan oleh tingkah laku, walaupun pada hakikatnya sifat itu bisa dibentuk oleh seseorang ketika beradaptasi dengan lingkungan sekitar. Hal ini kembali dihadapkan kepada individu tersebut cukup benarkah berada di dalam dimensi tersebut, ataukah dimensi kehidupan tersebut menjadi faktor yang membentuk perubahan sifat, sikap, dan perilaku, sehingga bukan dampak pergaulan yang positif yang didapatkan justru dampak pergaulan yang negatif yang didapatkan (Semium, 2012:55).

Sisi psikologis manusia mencerminkan jati dirinya. Kaitan teori-teori psikologi dan penokohan, artinya kembali kedalam unsurunsur interinsik sebuah drama.Unsur interinsik drama menyikapi amanat yang muncul dari karakter tokoh yang diperankan. Penonton akan secara langsung maupun tidak langsung merasakan perwatakan tokoh ketika tokoh tesebut berbicaradan bertindak di dalam adegan. Kasanah dari seorang tokoh berkorelasi dengan psikologis manusia dalam kehidupan nyata, tetapi bedanya jika dalam sebuah pertunjukan teater pemeran yang disebut aktor atau aktris tidak membawa kepribadian diri yang sesungguhnya, 
Zul Id han, Analisis Karakter Pangeran Badar Dalam Pertunjukan Teater Bangsawan Palembang (Naskah Dua Korban Di Gunung Meru).

melainkan hanya menampilkan kepada penonton kepribadian rekaan yang sudah diangap sebagai konsep naskah dari sutradara. Seorang aktor, yang berada pada set area, menghadapi suatu kehidupan yang sejati atau imajiner. Kehidupan yang jauh dari kepribadian seorang aktor, bahkan harus ditampilkan seorang aktor ketika tuntutan peran yang harus ditampilkan jatuh kepada seorang aktor, dan tugas sang aktor adalah keluar dari kehidupan pribadinya dan menjadi aktor dalam tuntutan naskah (Waluyo, 2007:34).

Tulisan Soediro Satoto dalam analisis drama dan teater, untuk mengambarkan karakter atau watak dari seorang tokoh dalam lakon membaginya kedalam tiga dimensi,

1. Dimensi fisologis, ialah ciri-ciri badan misalnya, usia, jenis kelamin, keadaan tubuhnya, ciri-ciri muka.

2. Dimensi sosiologis, ialah ciri-ciri kehidupan masyarakat, misalnya status sosial, pekerjaan, jabatan, peranan dalam masyarakat, tingkat pendidikan, kehidupan pribadi, pandangan hidup, agama, kepercayaan ideologi, aktifitas sosial, bangsa, suku dan keturunan.

3. Dimensi psikologis, ialah latar belakang kejiwaan misalnya; temperamen, keinginan dan perasaan pribadi, sikap dan perilaku (Satoto, 2012:41-42).

Dari ketiga dimensi yang telah diutarakan tersebut, maka dapat diutarakan gambaran mengenai tokoh Pangeran Badar, yaitu menurut dimensi fisologis, Pangeran Badar adalah seorang laki-laki yang memiliki ciri-ciri badan yang tegap tinggi usia sekitar 30 tahun, kemudian memiliki wajah tampan dan berkulit putih. Dimensi sosiologis Pangeran Badar adalah hidup dengan segala macam kesenangan di kerajaan, menjadi pangeran, memiliki kekayaan dan berasal dari lingkungan bangsawan. Dimensi psikologis Pangeran Badar memiliki sifat yang sombong, selalu berbicara kasar dan memiliki perilaku yang arogan.
Pikiran dan perasaan dapat ditemukan dalam teknik cakapan dan tingkah laku.Artinya, penuturan itu sekaligus untuk mengambarkan pikiran dan perasaan tokoh.Untuk memahami tokoh Pangeran Badar dalam lakon dapat dilihat dari reaksi tokoh. Reaksi tokoh dimaksudkan sebagai reaksi terhadap suatu kejadian, masalah, keadaan, kata-kata, dan sikap tingkah laku orang lain yang bersifat rangsangan dari luar diri tokoh. Reaksi tokoh terhadap hal-hal tersebut dapat dipandang sebagai bentuk penampilan yang mencerminkan sifat-sifat kediriannya. Reaksi Pangeran Badar terhadap tokoh Jamal, dalam dialog menegaskan, bahwa Pangeran Badar melakukan penghinaan dan merendahkan status sosial, semua itu tercermian pada percakapan adegan ke IV ketika Jamal mempertanyakan apa yang sudah dilakukan kepada adiknya.

Kutipan Dialog

Kurus : ampun pangeran ada yang ingin bertemu dengan pangeran, seorang laki-laki desa

Pangeran : kau tanya siapa laki-laki itu, Badar ada urusan apa dia mencari diriku

Kurus : saya tidak tau pangeran tapi dia iggin bertemu

Pangeran : jika dia sangat ingin bertemu

Badar dengan $\mathrm{ku}$ persilahkan dia masuk

Jamal : Badar...badar... berarti kau ini yang bernama pangeran Badar

Pangeran : ya aku Pangeran Badar

Badar

Jamal : Bagus, satu ulu sungai oren banyak orang menjual jamu Kau kucari-cari dari kemarin hari ini baru bertemu

Pangeran : hey anak muda apa maksudmu Badar datang kemari dan bertemu padaku

Jamal : aku ingin bertanya padamu apakah kau kenal dengan gadis bernama Jamila 
Pangeran : Jamila, aku kenal dengan Badar Jamila

Jamal : lalu kau berbuat apa padanya, dan kau agap siapa dia dalam hidupmu

Pangeran : Jamila, dulu memang Badar kekasihku tapi asal kau tau aku tidak mungkin memiliki kekasih seorang perempuan desa perempuan kampung

Jamal : asal kau tau badar akulah kakak nya dan aku merasa sakit hati atas perlakuanmu

Pangeran : hey orang desa, kau tau Badar kesalahan mu datang kemari kau tidak ku undang datang kesini bahkan kau berani sekali menantangku bahkan berkata kasar kepada seorang pangeran.

Jamal : Aku berbicara kepadamu bukan kepada rakyat dan pangeran tapi antara laki-laki dan laki-laki. Jika kau benar laki-laki temui aku di bukit gunung meru kita bertarung di sana

Pangeran : Hahahaa jadi kau menantangku Badar hahaha..hey laki-laki desa asal kau tau aku tidak akan gentar sedikitpun akan tantanganmu. akan aku terima tantanganmu

Sama halnya seperti alur dan plot, perwatakan dan penokohan juga termasuk unsur intrinsik dalam sebuah cerita atau karya sastra. Jenis-jenis watak tokoh dalam drama digolongkan pernannya dalam lakuan dan fungsinya. Berdasarkan peran dalam lakuan ada tiga macam tokoh yaitu tokoh protagonist, tokoh antagonis, dan tokoh tritagonis.

\section{Tokoh Protagonis}

Tokoh protagonis adalah tokoh yang berperan sebagai motor pengerak lakon. Biasanya, dalam sebuah lakon ada satu atau dua tokoh protagonist yang dibantu tokohtokoh lain yang terlibat dalam lakuan. Oleh karena perannya sebagai protagonis, tokoh tersebut merupakan tokoh yang pertama-tama menghadapi masalah yang terbelit dengan kesulitan-kesulitan. Tokoh protagonis dalam cerita adalah Jamal saudara laki-laki dari Jamila.Dalam cerita Jamal datang sebagai sosok yang membela kehormatan adiknya dan sebagai kesatria yang akhirnya mengakhiri kejahatan dari Pangeran Badar.

\section{Tokoh Antagonis}

Tokoh antagonis adalah tokoh yang berperan sebagai penghalang dan masalah bagi protagonis. Biasanya ada satu orang tokoh antagonis dan beberapa tokoh yang berperan sebagai penghalang bagi tokoh protagonis. Tokoh antagonis dalam cerita ini adalah Pangeran Badar, sikap dan pembawaan pangeran yang kejam dan sombong terlihat dari adegan yang dimainkan.

\section{Tokoh Tritagonis}

Tokoh tritagonis adalah tokoh yang berpihak pada protagonis dan antagonis, atau menjadi penengah antara tokoh protagonis dan antagonis. Dalam lakon Dua Korban di Gunung Meru tidak ada peran penegah dalam adegan semua masalah-masalah dan konflik dalam cerita diselesaikan oleh tokoh sentral dan tokoh utama.

Berdasarkan fungsinya dalam lakon dapat dibedakan tokoh sentral, tokoh utama, dan, tokoh pembantu.

\section{a. Tokoh Sentral}

Tokoh sentral adalah tokoh yang paling menentukan dalam seluruh lakon drama.Tokoh sentral biasanya adalah tokoh protagonis dan tokoh antagonis. Dalam lakon Dua Korban di Gunung Meru yang menjadi tokoh sentral disini adalah Pangeran Badar dan Jamila, keduanya adalah tokoh yang menentukan berjalannya cerita karena, dari mulai awal adegan, sampai akhir adegan kedua tokoh ini yang menjadi inti dalam cerita dan secara garis besar lakon ini 
Zul Id han, Analisis Karakter Pangeran Badar Dalam Pertunjukan Teater Bangsawan Palembang (Naskah Dua Korban Di Gunung Meru).

mengkisahkan hubungan antara Pangeran Badar dan Jamila.

\section{b. Tokoh Utama}

Tokoh utama adalah pelaku yang diutamakan dalam sebuah lakon. Tokoh ini banyak muncul dan banyak dibicarakan .Tokoh utama dalam Lakon Dua Korban di Gunung Meru ini adalah Jamal. Saudara lakilaki dari tokoh Jamila dalam lakon ini merupakan sosok protagonis yang digambarkan sebagai pelaku yang diutamakan, karena kehadirannya dalam adegan sebagai lawan dari Pangeran Badar. Kehadirannya menjadi akhir dari semua kesombongan Pangeran Badar yang takluk di tangan Jamal.

\section{c. Tokoh Pembantu}

Adalah tokoh-tokoh yang hadir untuk melengkapi suasana tambahan dalam jalinan cerita. Kehadiran mereka dimunculkan menurut kebutuhan cerita di dalam pertunjukan. Tokoh pembantu dalam Lakon Dua Korban di Gunung Meru terdiri dari, para pengawal Pangeran Badar, Cebol, dan Kurus serta teman Jamal dan Mak Siti.

\section{Kesimpulan}

Lakon Dua Korban Di Gunung Meru syarat nilai-nilai sosial di dalamnya, banyak amanat yang bisa dikaji dalam lakon tersebut, dan bisa dijadikan pedoman di tengah-tengah masyarakat. Dalam tulisan ini watak diartikan sebagai sikap, perilaku oleh tokoh sehingga dari uraian sebelumnya bisa diambil kesimpulan, bahwa karakter Pangeran Badar yang bersifat jahat tidak boleh ditiru atau dicontoh oleh siapapun, karena sikap dan sifat seperti Pangeran Badar tidak baik. Ambillah sisi positif dari seorang Jamal yang memiliki jiwa kesatria, berani membela harga dirinya, tidak pernah ingkar janji, cinta kasih terhadap keluarga, bijaksana dalam bertindak, dan menjadi orang yang seportif. Itulah ciri karakter yang baik yang dapat menjadi panutan.
Sikap, sifat dan pola pikir seorang tokoh sebagai aktor dalam dunia pertunjukan teater dipengaruhi oleh tuntutan sutradara dan keinginan yang harus dimunculkan pada sebuah karakter dalam permainan peran. Sesuai dengan tulisan Sodiro Satoto dalam analisis drama dan teater untuk mengambarkan karakter atau watak dari seorang tokoh dalam lakon membaginya ke dalam tiga dimensi yaitu, dimensi fisiologis, dimensi sosiologis, dan dimensi psikologis.

Untuk memahami sebuah karakter atau watak di dalam karya rekaan ilmu psikologi juga berperan untuk memunculkan dimensidimensi dari segala macam aspek yang dapat timbul pada diri manusia, meliputi pola pikirnya, nada bicaranya, penampilan fisiknya dan semua itu menjadi konkret ketika perspektif psikologi dikaitkan dengan unsurunsur drama.

\section{DAFTAR PUSTAKA}

Ambar, Sari, Mei. "Analisis Karakter dan Konflik Tokoh Utama dalam Novel Bochan Karya Nathusme Sousakhi”. Tesis S2 Program Studi Sastra Jepang Universitas Dian Nuswantoro Surabaya, 2011.

Aminuddin. Teori Penokohan. Yogyakarta: Pustaka Pelajar, 1984.

Anirun, Suyatna. Menjadi Sutradara. Bandung: STSI Press Bandung, 2002.

Arikunto, Suharsini. Prosudur Penelitian Suatu Pendekatan Peraktik. Jakarta: Rineka, cipta 2010.

Asmara, Adhy. Cara Menganalisa Drama. Yogyakarta: Nur Cahaya, 1983.

Azhari, Muhammad. Manajemen Teater. Palembang: Unsri, 2009.

Bertens, K. Etika. Jakarta: Gramedia Pustaka Utama, 1993. 
Boskoff, Alvin. "Recent Theories Of Social Change" dalam Werner J. Chanman dan Alvin Boskoff (ed),Sociology and Hystory: Theory and Research. London: The Free Press of Glence, 1964.

Budyatna, Muhammad. Teori Komunikasi Antar Pribadi. Jakarta: Kencana Prenada, 2011.

Bujang, Rahmah. Sejarah Perkembangan Drama Bangsawan Di Tanah Melayu Dan Singapura. Kuala Lumpur: Dewan Bahasa dan Pustaka, 1975.

Burhan, Burgin. Penelitian Kualitatif. Jakarta: Kencana, 2007.

Charles, Andrain. Kekuasaan. Yogyakarta: Yudistira, 1992

Damajanti, Irma. Psikologi Seni. Bandung: PT. Kiblat Buku Utama, 2006.

Danandjaja. Ilmu foklore. Jakarta: Erlangga, 2007.

Danim. Metode Penelitian. Bandung: Yrama Widya, 2002.

Goodman, J Douglas, dan George Ritzer. Teori Sosiologi Modern. Terj. Alimandan. Jakarta: Prenada Media, 2004.

Haryanto. Kekuasaan dan Kedudukan. Yogyakarta: Kanisius, 2005.

Hasanudin, WS. Drama dalam karya dua dimensi. Bandung: Angkasa, 2009.

Haviland, William A. Antropologi. Terj. Sahid. Jakarta: Erlangga,1993.

Ismet, Adang. Seni Peran. Bandung: Kelir, 2007.

Jayanti, Novi Dwina. "Kepribadian Tokoh Uemura Kana Dalam Drama Toire No Kamisama Karya Uemura
Kana" Jurnal Teknologi Informasi Bahasa VOl. 32 NO. 02 Program Studi Sastra Jepang Universitas Dian Nuswantoro: Surabaya, 2012.

Joseph, Murphy. Rahasia Kekuatan Pikiran Bawah Sadar. Jakarta: Spektrum, 2002.

Margono, Metode Penelitian Kualitatif. Jakarta: Rineka Abadi, 2006.

Maslow, Abraham, H. Motivasi dan Kepribadian. Terj. Nurul Iman. Jakarta: Midas Surya Grafindo, 1994.

Murgiyanto, Sal dan Made, Bandem. Teater Tradisonal. Yogyakarta: Kanisius, 1964.

Nurgiyantoro, Burhan. Teori Pengkajian fiksi. Yogyakarta: Gadjah Mada University Press, 1994.

Rantika. Membaca Ekpresi Lawan Bicara. Yogyakarta: Kanisius, 2003.

Rendra, WS. Seni Drama Untuk Remaja. Jakarta: PT. Pustaka Jaya,1993.

Risnawati dan Ghufron. Teori -Teori Psikologi. Yogyakarta: Ar-ruzz Media, 2010.

Robert, A. Dahl. Kekuasaan Pemimpin. Terj. Ramasari. Bandung: Cipta Buana, 1978.

Sahid, Nur. Semiotika Teater. Yogyakarta: ISI Yogyakarta, 2004.

Samsuri. Analisis Bahasa. Jakarta: Erlangga, 1991.

Saputra, Puji. Legenda Gunung Semeru. Yogyakarta: Pustaka Pelajar, 2007.

Satoto, Soediro. "Tokoh dan Penokohan dalam Caturlogi Drama Orkes Madun karya Arifin A Noer". Disertasi Doktor dalam Ilmu Budaya Universitas Indonesia, 1998. 
Zul Id han, Analisis Karakter Pangeran Badar Dalam Pertunjukan Teater Bangsawan Palembang (Naskah Dua Korban Di Gunung Meru).

. Analisis Drama dan Teater

jilid 1. Yogyakarta: Ombak, 2012.

Analisis Drama dan Teater jilid 2. Yogyakarta: Ombak, 2012.

Semium, Yustinus. Teori-Teori Kepribadian. Yogyakarta: Kanisius, 2013.

Singh N.K. dan Mr. A.R. Agwan. Encyclopaedia of the Holy Qur'ân, New Delhi: balaji Offset, Edisi I h. 175, 2000.

Soedarsono. R.M. Seni Pertunjukan Indonesia di Era Globalisasi, Jakarta: Depdikbud, 1998.

Subagiyo, Heru. Jurnal. Estetika Lakon Tragedi. Yogyakarta : Jurnal ISI Yogyakarta, 2007.

Sugiyono. Penelitian Kualitatif dan Penelitian Kuantitatif. Jakarta : Bakti Adiyta Citra, 2008.

Tasman, A. Analisa Gerak dan Karakter. Surakarta: ISI Pres 2008.

Wadiyo. Akulturasi Dalam Kebudayaan, Jakarta: Prenada, 2006.

Walgito, Bimo. Pengantar Psikologi Umum. Yogyakarta: Kanisius, 2005.

Waluyo, J. Herman. Drama, Naskah, Pementasan, dan Pengajarannya. Surakarta: UNS, 2007. 